\title{
Role of apoptosis-related miRNAs in resveratrol- induced breast cancer cell death
}

\author{
R Venkatadri ${ }^{1,2}$, T Muni $^{1,2}$, AK V lyer ${ }^{1}$, JS Yakisich $^{1}$ and N Azad ${ }^{*, 1}$
}

Breast cancer is the most frequently diagnosed cancer in women, and one of the leading causes of cancer-related deaths worldwide. Recent evidences indicate that dietary agents such as resveratrol may inhibit cancer progression through modulation of microRNAs (miRNAs). We demonstrate that resveratrol regulates apoptotic and cell cycle machinery in breast cancer cells by modulating key tumor-suppressive miRNAs including miR-125b-5p, miR-200c-3p, miR-409-3p, miR-122-5p and miR-542-3p. Resveratrol-mediated miRNA modulation regulates key anti-apoptotic and cell cycle proteins including Bcl-2, X-linked inhibitor of apoptosis protein and CDKs, which are critical for its activity. Modulating miRNAs with mimics or inhibitors further validated a key role for miR-542-3p in MCF-7 and miR-122-5p in MDA-MB-231 breast cancer cell death in response to resveratrol. In conclusion, this study reveals novel miRNAs modulated by resveratrol that have a key role in breast cancer cell death.

Cell Death and Disease (2016) 7, e2104; doi:10.1038/cddis.2016.6; published online 18 February 2016

Breast cancer is the second most common type of cancer in women, and the fifth most common cause of cancer-related deaths in the world. Nearly 200000 women get diagnosed and about 40000 die of breast cancer every year worldwide. ${ }^{1}$ Prolonged use of chemotherapeutic drugs against breast cancer mostly renders the drug ineffective because of development of resistance against the therapeutic agents. Identifying alternative treatments is crucial to reduce the mortality rate related to breast cancer.

Cell cycle arrest and apoptosis are considered important for therapeutics targeting cancer cells. It is often observed that cancer cells have altered cell cycle machinery. During the transition of a normal cell to cancerous state, cyclin-dependent kinases (CDKs) that govern coordinated initiation, progression and completion of cell cycle are overexpressed causing uncontrolled abnormal cell growth. ${ }^{2}$ Apoptosis or programmed cell death occurs naturally in all tissues to maintain tissue homeostasis and acts as a mechanism to eliminate unwanted cells. Cell division through the quiescence (G0) to the proliferative phases is controlled by the cell cycle. The DNA synthesis phase ( $\mathrm{S}$ phase) and the mitosis (M phase) are separated by the $\mathrm{G} 1$ and $\mathrm{G} 2$ phases. Several drugs targeting the cell cycle have entered clinical trials and some of the wellknown drugs currently used exhibit their effects by targeting the cell cycle. Cell cycle arrest is known to cause apoptosis and cell death in human malignancies. ${ }^{3,4}$ Apoptosis occurs via two controlled pathways: the extrinsic or death receptormediated pathway, which activates caspase-8; and the intrinsic or mitochondria-mediated pathway, which activates caspase-9. These caspases known as initiator caspases activate downstream effector caspases (caspase-3, -6, and $-7)$, which induce cleavage of several key cellular proteins to activate cell death. Cancer therapies like chemotherapy and many anticancer drugs primarily act by inducing apoptosis.

Natural plant-derived compounds, including resveratrol have been reported to induce apoptosis and cell cycle arrest in tumor cells. ${ }^{5-7}$ Resveratrol is a dietary agent found in a wide variety of plants like grapes, berries and peanuts and is known to have antioxidant and anti-inflammatory properties. It is emerging as a promising anticancer agent because of its chemopreventive and pro-apoptotic properties. ${ }^{8-11}$ Resveratrol has been shown to have a crucial role in apoptosis induction in human breast cancer cells. ${ }^{12,13}$ Moreover, studies show that several members of the mitogen-activated protein kinase signaling pathway are involved in this activation ${ }^{14}$ and the intrinsic mitochondrial pathway, via activation of caspase- 9 along with other key mediators calcium and calpain, is the major pathway involved in resveratrol-induced apoptosis. ${ }^{15}$

MicroRNAs (miRNAs) are emerging as potential diagnostic, prognostic and therapeutic tools for breast cancer treatment. ${ }^{16,17}$ MiRNAs are small non-coding single-stranded RNAs that negatively regulate gene expression by binding to mRNA and inhibiting translation. They control normal cell functions like cell cycle regulation, proliferation, differentiation and apoptosis. They have been implicated to have a critical role in the development and progression of various types of cancers including breast cancer. Owing to their significant and versatile roles, miRNAs are emerging as therapeutic tools for many cancers. Several miRNAs have been shown to be dysregulated in breast cancer tissues when compared with normal tissues. ${ }^{18}$ Modulation of tumor-suppressive miRNA by natural chemopreventive agents such as resveratrol has been shown to induce cell death via apoptosis in various cancer cells including prostate cancer cells. ${ }^{19}$ Interestingly, a

\footnotetext{
${ }^{1}$ Department of Pharmaceutical Sciences, Hampton University, Hampton, VA, USA

*Corresponding author: N Azad, Department of Pharmaceutical Sciences, Hampton University, Kittrell Hall, Hampton, VA 23668, USA. Tel: +1 757727 5071; Fax: +1 757 727 5840; E-mail: neelam.azad@ hamptonu.edu

${ }^{2}$ These authors contributed equally to this work.

Abbreviations: CDK, cyclin-dependent kinase; miRNA, microRNA; XIAP, X-linked inhibitor of apoptosis protein; IPA, ingenuity pathway analysis; IAP, inhibitor of apoptosis protein

Received 22.8.15; revised 11.12.15; accepted 29.12.15; Edited by G Calin
} 
link between resveratrol-induced apoptosis and miRNA modulation in relation to breast cancer has not been studied.

In this study, we investigated the anti-proliferative effects of miRNA modulation by resveratrol in breast cancer cells. We identified novel tumor-suppressive miRNAs differentially regulated by resveratrol in MCF-7 and MDA-MB-231 breast cancer cells that regulate apoptosis and cell cycle machinery. Furthermore, the rate-limiting miRNAs and their key target proteins that could serve as potential targets for tumor inhibition were identified. Elucidating the effect of resveratrolmediated miRNA modulation during breast cancer cell death may aid in better understanding of the underlying mechanisms that have a critical role in breast cancer.

\section{Results}

Caspase activation and apoptosis induction by resveratrol in breast cancer cells. We first characterized the apoptotic response to resveratrol treatment in MCF-7 and MDA-MB-231 human breast cancer cell lines. Cells were treated with various concentrations of resveratrol $(0-300 \mu \mathrm{M})$ and apoptosis was determined after $24 \mathrm{~h}$ by Hoechst assay. Figures $1 \mathrm{a}$ and $\mathrm{b}$ show that resveratrol treatment caused $\mathrm{a}$ dose-dependent increase in apoptosis over control level, as indicated by increased nuclear fluorescence and chromatin condensation of the treated cells. Furthermore, caspase activity assays using specific enzyme substrates for caspase8 and -9 showed a dose-dependent increase in caspase-8 and -9 activities in response to resveratrol in both MCF-7 and MDA-MB-231 cells (Figure 1c). The effect was more pronounced in MDA-MB-231 cells. Caspase activation and apoptosis induction was further confirmed by western blotting for various caspases (Figure 1d). Both cell lines were similarly treated with various concentrations of resveratrol for $24 \mathrm{~h}$ and analyzed for cell viability (Figures 1e and f). Resveratrol treatment significantly decreased cell viability in a dose-dependent manner in both MCF-7 and MDA-MB-231 cells. The $\mathrm{IC}_{50}$ values were $162.08 \pm 6.14$ and $123.67 \pm 18.11 \mu \mathrm{M}$ as determined by the MTT assay.

Resveratrol regulates apoptosis-related miRNAs in breast cancer cells. MCF-7 and MDA-MB-231 cells were treated with resveratrol and $12 \mathrm{~h}$ post-treatment real-time PCR amplification of isolated RNA using human apoptosis miRNA array, which analyzes a panel of 84 miRNAs known to be associated with cellular apoptosis was performed. Data analysis using the Qiagen (Valencia, CA, USA) online data analysis software revealed many miRNAs to be regulated as a result of apoptotic effect of resveratrol treatment versus control samples (Supplementary Table 1). Interestingly, most miRNAs from the panel of tested miRNAs were found to be downregulated in both cell lines. Table 1 shows miRNAs regulated by more than twofold in response to resveratrol treatment and miR-409-3p (1.6-fold change), which was the only one upregulated in MCF-7 cells. Thirty-five miRNAs were found to be downregulated in MCF-7 cells by more than twofold, among which miR-542-3p (over eightfold) and miR-125b-5p (over fivefold) showed the largest changes. In MDA-MB-231 cells, of the upregulated miRNAs, miR-122-5p showed a 37.6-fold change. Twenty-five miRNAs were found to be downregulated by $>2$-fold, among which miR-542-3p (over 11-fold) and miR-200c-3p (over 8-fold) showed the largest changes.

Resveratrol-mediated miRNA regulate key apoptosis and cell cycle proteins. For both MCF-7 and MDA-MB-231 cell lines, miRNAs that were most regulated (maximum fold change) by resveratrol treatment were selected for further analysis. Bioinformatics analysis with the aid of miRNA databases revealed as well as predicted experimentally validated targets of the identified miRNA (Table 2). Interestingly cyclins, caspases, Bcl-2 and many Bcl-2-like genes were targets for all miRNAs in both cell lines. The results of bioinformatics analysis were validated by western blot analysis. MCF-7 and MDA-MB-231 cells were treated with various concentrations of resveratrol and protein expression was analyzed. Resveratrol treatment caused a dosedependent downregulation of anti-apoptotic proteins including $\mathrm{Bcl}-2$ and $\mathrm{X}$-linked inhibitor of apoptosis protein (XIAP) and cell cycle proteins including CDK2, CDK4 and CDK6 (Figures 2a, b, $c$ and d). Furthermore, cell cycle analysis was performed to determine the distribution of different phases of cells using flow cytometry. Resveratrol treatment induced a dose-dependent G1-arrest in both MCF-7 and MDA-MB-231 cells. Comparatively, there was lower percentage of cells in the $S$ phase and significantly lower percentage in the G2/M phase for both MCF-7 and MDA-MB-231 cells (Figures 2e and f).

Modulation of key miRNAs regulates resveratrolmediated apoptosis. MCF-7 cells were transfected with miR-542-3p mimic and treated with resveratrol for $24 \mathrm{~h}$, followed by assessment of apoptosis and cell viability. Transfection with miR-542-3p mimic significantly reversed the effect of resveratrol on apoptosis and viability of MCF-7 cells as well as Bcl-2 and XIAP protein levels (Figures $3 a, b$ and $c$ ). Interestingly, the percentage of MCF-7 cells transfected with miR-542-3p mimic treated with resveratrol was lower in the $\mathrm{G} 1$ phase and higher in $\mathrm{S}$ and $\mathrm{G} 2 / \mathrm{M}$ phases as compared with non-transfected MCF-7 cells treated with resveratrol (Figure 3d). MDA-MB-231 cells were transfected with miR-122-5p inhibitor and treated with resveratrol for $24 \mathrm{~h}$. Transfection with miR-122-5p inhibitor reversed the effect of resveratrol on apoptosis, cell viability and $\mathrm{Bcl}-2$ and XIAP proteins (Figures $4 a$, b and c). Similar to MCF-7 cells, MDAMB-231 cells transfected with miR-122-5p inhibitor treated with resveratrol showed lesser cells in G1 phase and more cells in S and G2/M phases as compared with non-transfected MDA-MB-231 cells treated with resveratrol (Figure 4d).

Effect of resveratrol on breast cancer miRNAs. Modulation of breast cancer-related miRNAs by resveratrol in MCF-7 and MDA-MB-231 cells was investigated by quantitative realtime PCR using a human breast cancer array, which analyzes a panel of 84 miRNAs known to be associated with breast cancer (Supplementary Table 2). The data were analyzed using the miScript miRNA PCR Array Data Analysis portal (Qiagen), and a clustergram of the array data for each cell line was generated (Supplementary Figure 1). Breast cancer miRNAs regulated by more than twofolds in response to 
a

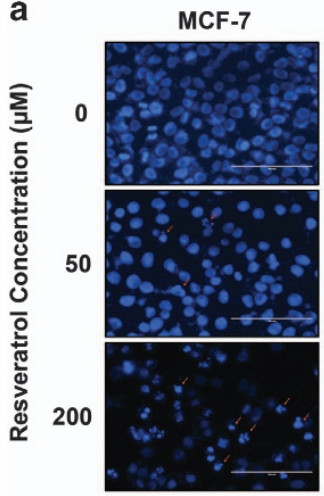

C

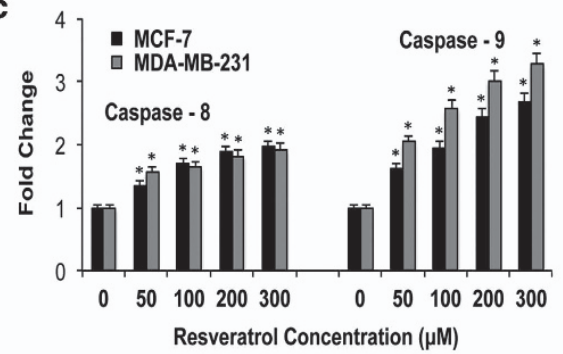

e

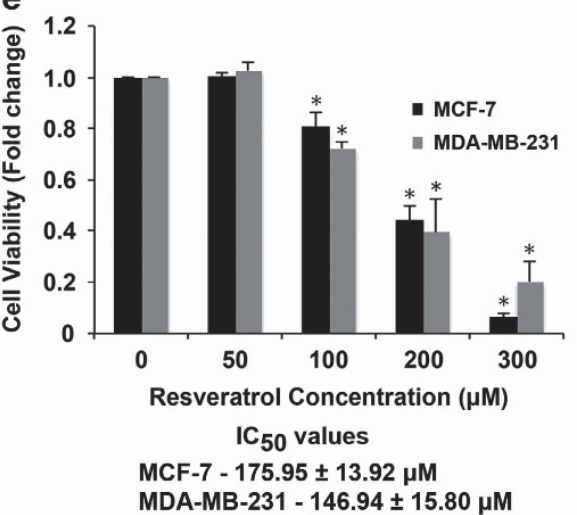

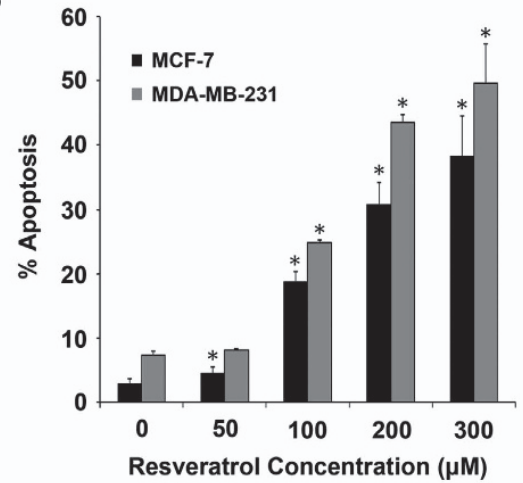

d Resveratrol Concentration $(\mu \mathrm{M})$

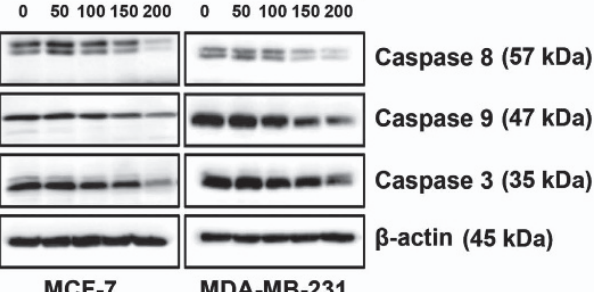

f

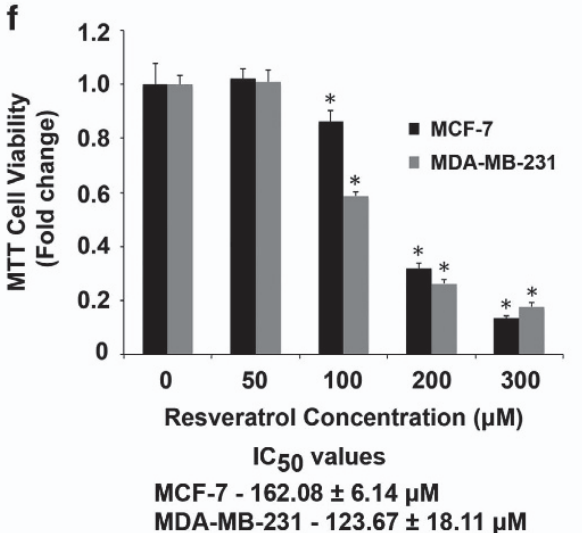

Figure 1 Resveratrol induces apoptosis in breast cancer cells. (a) Representative fluorescence micrographs of MCF-7 and MDA-MB-231 cells treated with resveratrol (0-200 $\mu \mathrm{M}$ ) for $24 \mathrm{~h}$ showing intensely condensed chromatin and/or fragmented nuclei (shown by arrows); scale bar, $100 \mu \mathrm{M}$. (b) MCF-7 and MDA-MB-231 cells were treated with indicated concentrations of resveratrol for $24 \mathrm{~h}$ and analyzed for apoptosis by Hoechst 33342 assay. (c) Fluorometric assay of caspase activity in cells treated with resveratrol $(0-300 \mu \mathrm{M})$ for $12 \mathrm{~h}$. Cell lysates (50 $\mu \mathrm{g}$ of protein) were prepared and analyzed for caspase activity using the fluorometric substrates IETD-AMC and LEHD-AMC for caspase-8 and -9 , respectively. Plots show relative fluorescence intensity over untreated control. (d) Cell lysates (30 $\mu \mathrm{g}$ proteins) from resveratrol (0-200 $\mu \mathrm{M})$ treated MCF-7 and MDAMB-231 cells were analyzed for caspase activation by western blotting. Representative data from three or more independent experiments are shown. (e) MCF-7 and MDAMB-231 cells were treated with indicated concentrations of resveratrol for $24 \mathrm{~h}$ and cell viability was assessed by CellTiter-Glo Luminescent Cell Viability Assay. (f) MCF-7 and MDA-MB-231 cells were treated with indicated concentrations of resveratrol for $24 \mathrm{~h}$ and assessed by MTT Assay. Data represent mean values \pm S.E.M. of triplicate determinations from three or more independent experiments. ${ }^{*} P<0.05$ versus untreated control

resveratrol treatment is shown in Figure 5 and Supplementary Table 3. Two miRNAs were upregulated in both MCF-7 and MDA-MB-231 cells by more than twofolds, of which miR-199a-5p was common to both. A total of 18 miRNAs in MCF-7 and 9 miRNAs in MDA-MB-231 cells were downregulated by more than twofolds with resveratrol treatment. Notable miRNAs that were common in both cell lines were miR-199a-5p, miR-125b-1-3p, miR-140-5p and miR-20a-5p. The expression profiles of miRNAs identified for each cell line were subjected to ingenuity pathways analysis (IPA), and a network map of potential proteins and pathways were generated using path design within the IPA core analysis tool for both MCF-7 and MDA-MB-231 cells (Figures $6 \mathrm{a}$ and b). IPA shows that several key apoptotic proteins already identified in this study form the central nodes of the network pathways predicted for both MCF-7 and MDA-MB-231 cells.

\section{Discussion}

Naturally occurring chemopreventive agents have gained significant interest as reports of their effect on modulating 
miRNAs to inhibit cancer growth and metastasis are becoming evident. $^{20-23}$ Resveratrol is known to induce apoptosis in breast cancer cells. ${ }^{24-27}$ We validated the effect of resveratrol on cell viability and apoptosis in MCF-7 and MDA-MB-231 cells (Figure 1). Although resveratrol-induced activation of both caspase- 8 and -9 , we observed that the mitochondrial

Table 1 Apoptosis miRNA microarray data for MCF-7 and MDA-MB-231 cells treated with $200 \mu \mathrm{M}$ resveratrol for $12 \mathrm{~h}$ as compared with untreated control cells showing at least a twofold change

\begin{tabular}{|c|c|c|}
\hline ID & Function & Fold regulation \\
\hline \multicolumn{3}{|l|}{ MCF-7 } \\
\hline hsa-miR-409-3p & Targets both pro- and anti-apoptotic genes & 1.6057 \\
\hline hsa-let-7g-5p & Pro-apoptotic; targets anti-apoptotic genes & -2.4911 \\
\hline hsa-miR-101-3p & Pro-apoptotic; targets anti-apoptotic genes & -2.8615 \\
\hline hsa-miR-125b-5p & Targets both pro- and anti-apoptotic genes & -5.7231 \\
\hline hsa-miR-128 & Pro-apoptotic & -2.8615 \\
\hline hsa-miR-143-3p & Pro-apoptotic & -3.0669 \\
\hline hsa-miR-17-5p & Targets both pro- and anti-apoptotic genes & -2.4911 \\
\hline hsa-miR-181a-5p & Anti-apoptotic, targets both pro- and anti-apoptotic genes & -2.3243 \\
\hline hsa-miR-181c-5p & Targets both pro- and anti-apoptotic genes & -3.523 \\
\hline hsa-miR-181d & Targets both pro- and anti-apoptotic genes & -2.6699 \\
\hline hsa-miR-183-5p & Anti-apoptotic & -2.1686 \\
\hline hsa-miR-186-3p & Anti-apoptotic & -2.1686 \\
\hline hsa-miR-192-5p & Targets both pro- and anti-apoptotic genes & -2.8615 \\
\hline hsa-miR-194-5p & Targets anti-apoptotic genes & -3.7758 \\
\hline hsa-miR-195-5p & Pro-apoptotic; targets anti-apoptotic genes & -3.2871 \\
\hline hsa-miR-210 & Anti-apoptotic & -2.8615 \\
\hline hsa-miR-212-3p & Pro-apoptotic & -3.7758 \\
\hline hsa-miR-214-3p & Anti-apoptotic & -4.0468 \\
\hline hsa-miR-23a-3p & Either anti- or pro-apoptotic & -2.8615 \\
\hline hsa-miR-26b-5p & Pro-apoptotic & -3.0669 \\
\hline hsa-miR-29a-3p & Pro-apoptotic, targets both pro- and anti-apoptotic genes & -2.0234 \\
\hline hsa-miR-29b-3p & Either anti- or pro-apoptotic, targets both pro- and anti-apoptotic genes & -2.1686 \\
\hline hsa-miR-29c-3p & Pro-apoptotic, targets both pro- and anti-apoptotic genes & -3.0669 \\
\hline hsa-miR-30b-5p & Anti-apoptotic, targets both pro- and anti-apoptotic genes & -3.0669 \\
\hline hsa-miR-30c-5p & Pro-apoptotic & -2.0234 \\
\hline hsa-miR-31-5p & Pro-apoptotic & -3.523 \\
\hline hsa-miR-34a-5p & Pro-apoptotic, targets both pro- and anti-apoptotic genes & -2.4911 \\
\hline hsa-miR-34c-5p & Either anti- or pro-apoptotic & -3.0669 \\
\hline hsa-miR-378a-3p & Anti-apoptotic & -2.1686 \\
\hline hsa-miR-451a & Targets both pro- and anti-apoptotic genes & -3.7758 \\
\hline hsa-miR-497-5p & Pro-apoptotic, targets both pro- and anti-apoptotic genes & -2.1686 \\
\hline hsa-miR-512-5p & Pro-apoptotic; targets anti-apoptotic genes & -4.6486 \\
\hline hsa-miR-542-3p & Targets anti-apoptotic genes & -8.0937 \\
\hline hsa-miR-7-5p & Targets anti-apoptotic genes & -3.7758 \\
\hline hsa-miR-9-5p & Targets anti-apoptotic genes & -3.2871 \\
\hline hsa-miR-98-5p & Anti-apoptotic & -2.6699 \\
\hline \multicolumn{3}{|l|}{$M D A-M B-231$} \\
\hline hsa-miR-122-5p & Targets anti-apoptotic genes & 37.6175 \\
\hline hsa-let-7a-5p & Either anti- or pro-apoptotic; targets both pro- and anti-apoptotic genes & -4.4898 \\
\hline hsa-miR-101-3p & Pro-apoptotic; targets anti-apoptotic genes & -2.9622 \\
\hline hsa-miR-106b-5p & Anti-apoptotic & -2.7638 \\
\hline hsa-miR-134 & Targets pro-apoptotic genes & -5.5277 \\
\hline hsa-miR-141-3p & Anti-apoptotic & -3.1748 \\
\hline hsa-miR-143-3p & Pro-apoptotic & -3.1748 \\
\hline hsa-miR-146a-5p & Targets both pro- and anti-apoptotic genes & -3.4027 \\
\hline hsa-miR-15a-5p & Targets both pro- and anti-apoptotic genes & -2.5787 \\
\hline hsa-miR-16-5p & Pro-apoptotic, targets both pro- and anti-apoptotic genes & -2.2449 \\
\hline hsa-miR-181b-5p & Pro-apoptotic, targets both pro- and anti-apoptotic genes & -3.4027 \\
\hline hsa-miR-181d & Targets both pro- and anti-apoptotic genes & -2.2449 \\
\hline hsa-miR-183-5p & Anti-apoptotic & -2.5787 \\
\hline hsa-miR-186-3p & Anti-apoptotic & -3.9086 \\
\hline hsa-miR-192-5p & Targets both pro- and anti-apoptotic genes & -2.4061 \\
\hline hsa-miR-200c-3p & Pro-apoptotic & -8.3784 \\
\hline hsa-miR-212-3p & Pro-apoptotic & -2.4061 \\
\hline hsa-miR-26b-5p & Pro-apoptotic & -2.2449 \\
\hline hsa-miR-30b-5p & Anti-apoptotic, targets both pro- and anti-apoptotic genes & -3.9086 \\
\hline hsa-miR-32-5p & Targets pro-apoptotic genes & -4.8121 \\
\hline hsa-miR-34a-5p & Pro-apoptotic, targets both pro- and anti-apoptotic genes & -2.7638 \\
\hline hsa-miR-497-5p & Pro-apoptotic, targets both pro- and anti-apoptotic genes & -2.0946 \\
\hline hsa-miR-512-5p & Pro-apoptotic; targets anti-apoptotic genes & -2.9622 \\
\hline hsa-miR-542-3p & Targets anti-apoptotic genes & -11.0553 \\
\hline hsa-miR-7-5p & Targets anti-apoptotic genes & -4.1892 \\
\hline hsa-miR-98-5p & Anti-apoptotic & -2.7638 \\
\hline
\end{tabular}


Table 2 Shortlisted resveratrol-induced miRNAs in MCF-7 and MDA-MB-231 breast cancer cells and their potential apoptotic targets

\begin{tabular}{|c|c|c|c|c|c|c|c|c|c|}
\hline miRNA (SANGER ID) & Prediction format & p53 & BCL2 & $\mathrm{BAX}$ & FAS & Caspases & BRCA & Cyclins & Other \\
\hline \multicolumn{10}{|l|}{$M C F-7$} \\
\hline \multirow{2}{*}{$\begin{array}{l}\text { hsa-miR-409-3p } \\
\text { MIMAT0001639 }\end{array}$} & Binding to $3^{\prime}$ UTR & & BCL2L15 & & & & & & \\
\hline & $\begin{array}{l}\text { Multiple prediction } \\
\text { (DIANAmT, miRanda, } \\
\text { miRDB, miRWalk, } \\
\text { Targetscan) }\end{array}$ & & $\begin{array}{l}\text { BCL2, } \\
\text { BCL2L2, } \\
\text { BCL2L11, } \\
\text { BCL2L13, } \\
\text { BCL2L15 }\end{array}$ & & & $\begin{array}{l}\text { CASP2, } \\
\text { CASP3, } \\
\text { CASP4, } \\
\text { CASP8, } \\
\text { CASP10 }\end{array}$ & & $\begin{array}{l}\text { Many cyclins } \\
\text { and CDKs }\end{array}$ & \\
\hline \multirow{2}{*}{$\begin{array}{l}\text { hsa-miR-542-3p } \\
\text { MIMAT0003389 }\end{array}$} & Binding to $3^{\prime}$ UTR & & & & & & & CDKN1A & BIRC5 \\
\hline & $\begin{array}{l}\text { Multiple prediction } \\
\text { (DIANAmT, miRanda, } \\
\text { miRDB, miRWalk, } \\
\text { Targetscan) }\end{array}$ & & $\begin{array}{l}\text { BCL2, } \\
\text { BCL2L15 }\end{array}$ & & & $\begin{array}{l}\text { CASP2, } \\
\text { CASP6, } \\
\text { CASP10 }\end{array}$ & & $\begin{array}{l}\text { Many cyclins } \\
\text { and CDKs }\end{array}$ & \\
\hline \multirow{2}{*}{$\begin{array}{l}\text { hsa-miR-125b-5p } \\
\text { MIMAT0000423 }\end{array}$} & Binding to $3^{\prime}$ UTR & & $\begin{array}{l}\text { BCL2L13, } \\
\text { BCL2L14 }\end{array}$ & & & CASP2 & & CCNJ & \\
\hline & $\begin{array}{l}\text { Multiple prediction } \\
\text { (DIANAmT, miRanda, } \\
\text { miRDB, miRWalk, } \\
\text { Targetscan) }\end{array}$ & & $\begin{array}{l}\text { BCL2, } \\
\text { BCL2L1, } \\
\text { BCL2L2, } \\
\text { BCL2L11, } \\
\text { BCL2L12, } \\
\text { BCL2L13, } \\
\text { BCL2L14 }\end{array}$ & & & $\begin{array}{l}\text { CASP2, } \\
\text { CASP6, } \\
\text { CASP7, } \\
\text { CASP9, } \\
\text { CASP10 }\end{array}$ & BRCC3 & $\begin{array}{l}\text { Many cyclins } \\
\text { and CDKs }\end{array}$ & \\
\hline \multicolumn{10}{|l|}{$M D A-M B-231$} \\
\hline \multirow[t]{2}{*}{$\begin{array}{l}\text { hsa-miR-122-5p } \\
\text { MIMAT0000421 }\end{array}$} & Binding to $3^{\prime}$ UTR & & BCL2A1 & & & CASP6 & & $\begin{array}{l}\text { CCNG1, } \\
\text { CCNYL1 }\end{array}$ & \\
\hline & $\begin{array}{l}\text { Multiple prediction } \\
\text { (DIANAmT, miRanda, } \\
\text { miRDB, miRWalk, } \\
\text { Targetscan) }\end{array}$ & & $\begin{array}{l}\text { Many } \\
\text { BCL2L } \\
\text { proteins }\end{array}$ & & & $\begin{array}{l}\text { CASP2, } \\
\text { CASP6, } \\
\text { CASP10 }\end{array}$ & $\begin{array}{l}\text { BRCA1, } \\
\text { BRCC3 }\end{array}$ & $\begin{array}{l}\text { Many cyclins } \\
\text { and CDKs }\end{array}$ & \\
\hline \multirow{2}{*}{$\begin{array}{l}\text { hsa-miR-542-3p } \\
\text { MIMAT0003389 }\end{array}$} & Binding to 3 ' UTR & & & & & & & CDKN1A & BIRC5 \\
\hline & $\begin{array}{l}\text { Multiple prediction } \\
\text { (DIANAmT, miRanda, } \\
\text { miRDB, miRWalk, } \\
\text { Targetscan) }\end{array}$ & & $\begin{array}{l}\text { BCL2, } \\
\text { BCL2L15 }\end{array}$ & & & $\begin{array}{l}\text { CASP2, } \\
\text { CASP6, } \\
\text { CASP10 }\end{array}$ & & $\begin{array}{l}\text { Many cyclins } \\
\text { and CDKs }\end{array}$ & \\
\hline \multirow[t]{2}{*}{$\begin{array}{l}\text { hsa-miR-200c-3p } \\
\text { MIMAT0000617 }\end{array}$} & Binding to 3 ' UTR & & & & & CASP2 & & $\begin{array}{l}\text { CCNYL1, } \\
\text { CCNJ, CDK2 }\end{array}$ & \\
\hline & $\begin{array}{l}\text { Multiple prediction } \\
\text { (DIANAmT, miRanda, } \\
\text { miRDB, miRWalk, } \\
\text { Targetscan) }\end{array}$ & & $\begin{array}{l}\text { BCL2, } \\
\text { BCL2L11 }\end{array}$ & & & $\begin{array}{l}\text { CASP2, } \\
\text { CASP3, } \\
\text { CASP10 }\end{array}$ & $\begin{array}{l}\text { BRCA1, } \\
\text { BRCA2 }\end{array}$ & $\begin{array}{l}\text { Many cyclins } \\
\text { and CDKs }\end{array}$ & \\
\hline
\end{tabular}

\begin{tabular}{|c|c|c|c|c|c|c|c|c|}
\hline \multicolumn{9}{|c|}{ Summary table } \\
\hline \multirow[t]{2}{*}{ MiRNA } & \multicolumn{2}{|c|}{ Fold regulation } & \multirow[t]{2}{*}{ p53 } & \multirow[t]{2}{*}{ BCL2 } & \multirow[t]{2}{*}{ FAS } & \multirow[t]{2}{*}{ Caspases } & \multirow[t]{2}{*}{ BRCA } & \multirow[t]{2}{*}{ Cyclins } \\
\hline & MDA-MB-231 & MCF-7 & & & & & & \\
\hline $\begin{array}{l}\text { hsa-miR-122-5p } \\
\text { hsa-miR-200c-3p } \\
\text { hsa-miR-542-3p } \\
\text { hsa-miR-125b-5p } \\
\text { hsa-miR-409-3p }\end{array}$ & $\begin{array}{l}\square 37.6175 \\
\square-8.3784 \\
\square-11.0553\end{array}$ & $\begin{array}{l}\square-8.0937 \\
\square-5.7231 \\
\square 1.6057\end{array}$ & $\nabla$ & $\begin{array}{l}\square \\
\square \\
\square \\
\square \\
\square\end{array}$ & $\begin{array}{l}\square \\
\square\end{array}$ & $\begin{array}{l}\square \\
\square \\
\square \\
\square \\
\square\end{array}$ & $\begin{array}{l}\square \\
\square \\
\square\end{array}$ & $\begin{array}{l}\square \\
\square \\
\square \\
\square \\
\square\end{array}$ \\
\hline
\end{tabular}

caspase-9 pathway was the major apoptotic pathway involved in both MCF-7 and MDA-MB-231 cells (Figures 1c and d). Caspases are known to control the cell regulatory function that initiates the process of apoptosis and are an important feature of therapeutics that target cancer. ${ }^{28}$ Our observation also confirms previous reports on the intrinsic mitochondrial pathway being the major pathway involved in resveratrolinduced apoptosis, via activation of caspase- $9 .{ }^{15}$ Resveratrol has also been reported to activate the extrinsic pathway of cell death, including FAS-dependent apoptosis in HL-60 pro-myelocytic leukemia cells ${ }^{29,30}$ and TRAIL-induced apoptosis in prostate cancer cells. ${ }^{31}$ Furthermore, resveratrol exerted its pro-apoptotic effects by downregulating expression of key anti-apoptotic proteins belonging to the inhibitor of apoptosis (IAPs) family of proteins Bcl-2 and XIAP (Figures 2a and b) and also decreased expression of CDKs specific for G-phase arrest (Figures 2c and d). Cell cycle analysis by flow cytometry clearly showed a dose-dependent G1-arrest for both MCF-7 and MDA-MB-231 cells induced by resveratrol (Figures $2 e$ and f). Cell cycle regulation upon treatment with resveratrol seems to be cell-type specific - whereas resveratrol induces G0/G1-arrest in prostate cancer cells and 
a Resveratrol Concentration $(\mu \mathrm{M})$
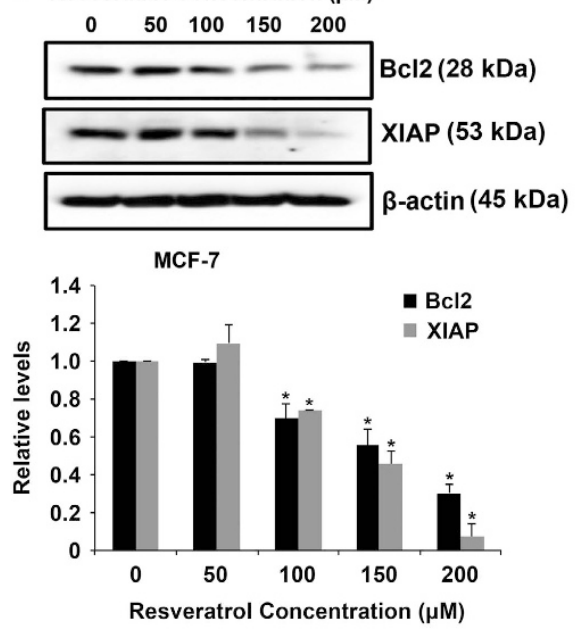

C Resveratrol Concentration $(\mu \mathrm{M})$
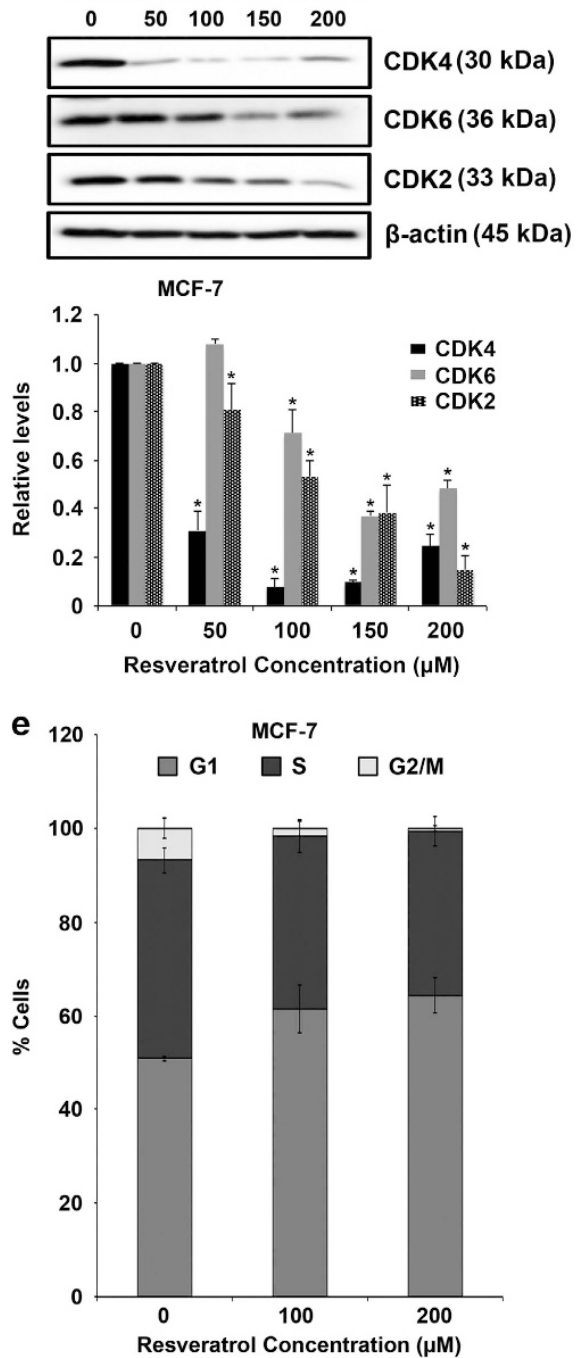

b
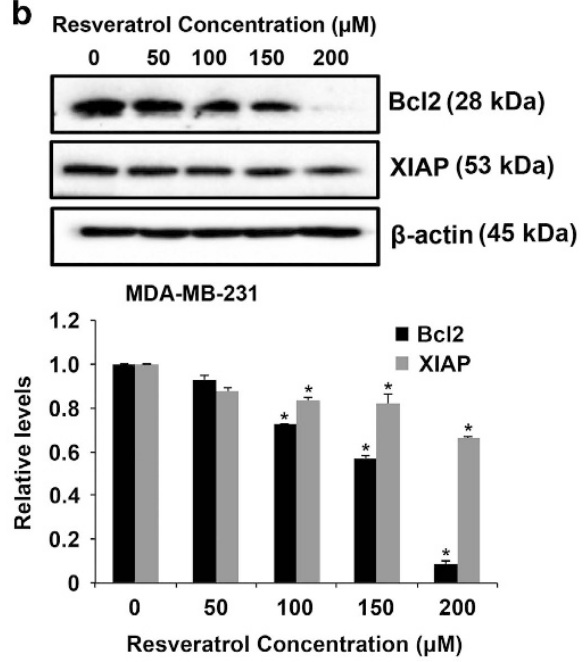

d Resveratrol Concentration $(\mu \mathrm{M})$
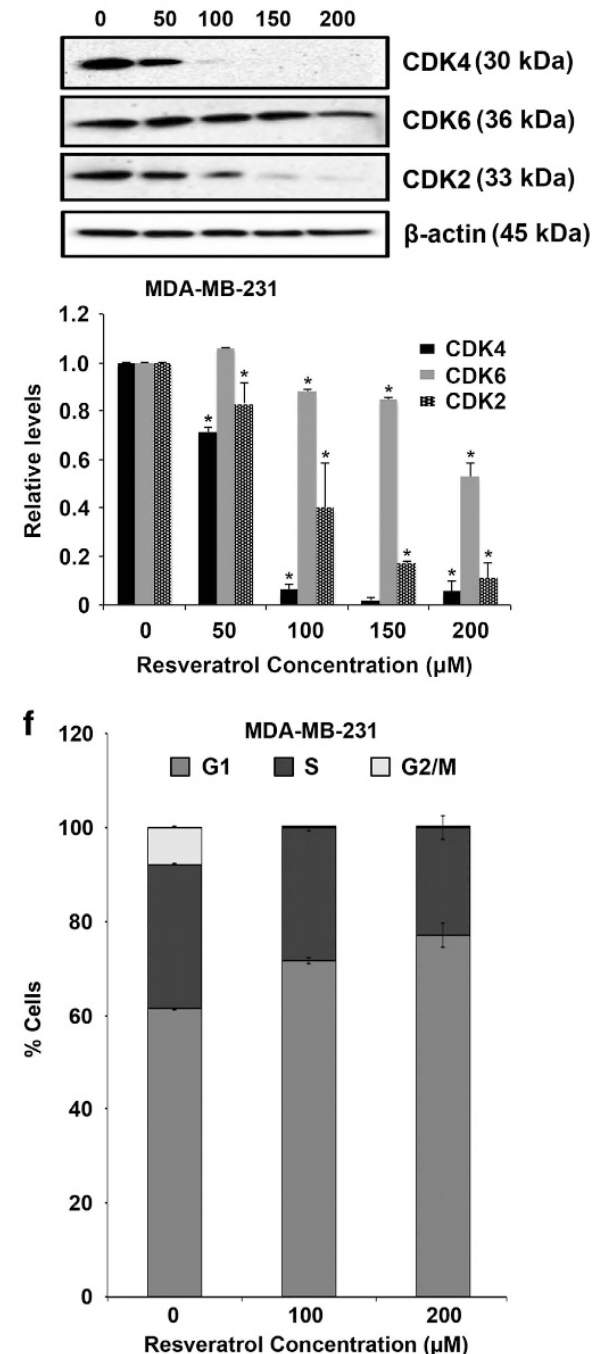

Figure 2 Resveratrol-mediated regulation of key apoptosis and cell cycle proteins. (a) MCF-7 and (b) MDA-MB-231 cells were treated with resveratrol (0-200 $\mu \mathrm{M}$ ) for $24 \mathrm{~h}$. Cell lysates were collected and analyzed for Bcl-2 and XIAP protein expression. (c) MCF-7 and (d) MDA-MB-231 cells were treated with resveratrol (0-200 $\mu \mathrm{M}$ ) for $24 \mathrm{~h}$ and cell lysates were analyzed for CDK4, CDK6 and CDK2. All blots were reprobed with $\beta$-actin antibody to confirm equal loading of the samples. The immunoblot signals were quantified by densitometry. Values are mean \pm S.E.M. $(n=3)$. ${ }^{*} P<0.05$ versus untreated control. (e) MCF-7 and (f) MDA-MD-231 cells treated with resveratrol were analyzed for cell cycle distribution using NovoCyte flow cytometer and ModFit 4.0.5 LT. Data represent mean values \pm S.E.M. from three independent experiments 


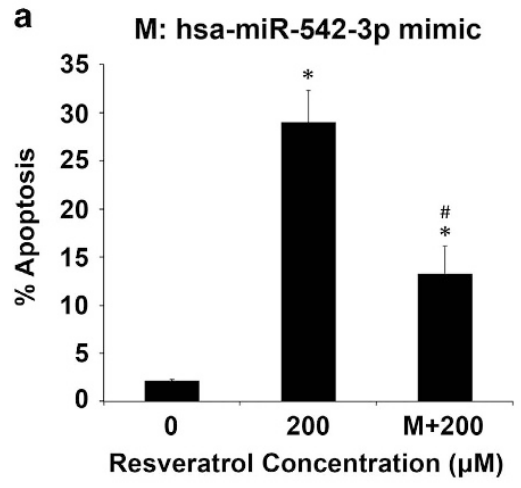

C
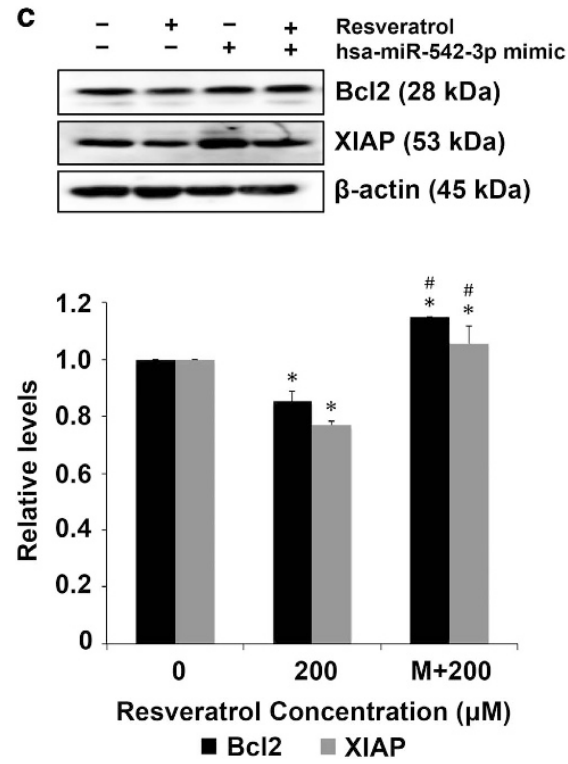

b M: hsa-miR-542-3p mimic

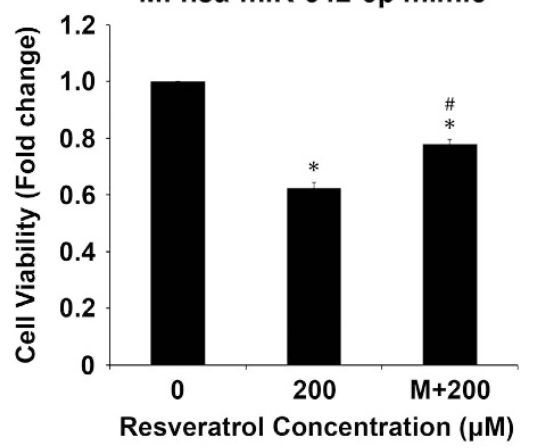

d 120

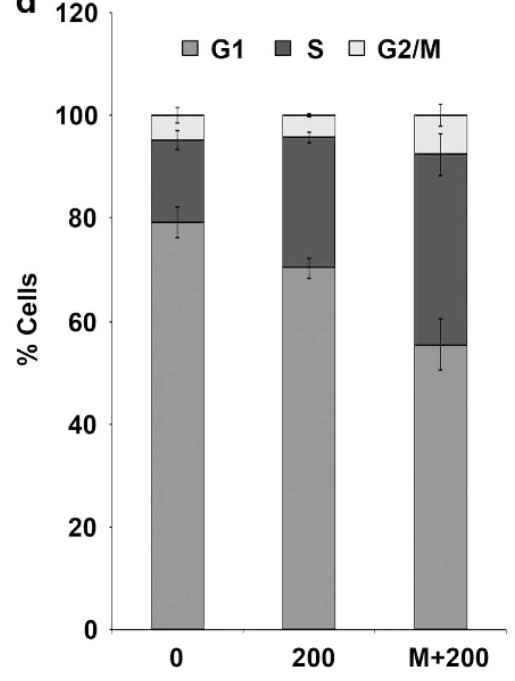

Resveratrol Concentration $(\mu \mathrm{M})$

Figure 3 Effect of miR-542-3p modulation in MCF-7 cells. (a) MCF-7 cells were transfected with miR-542-3p mimic (100 nM) for $40 \mathrm{~h}$ and then treated with resveratrol for $24 \mathrm{~h}$. Apoptosis induction was assessed by Hoechst 33342 staining. (b) MCF-7 cells were transfected with miR-542-3p mimic (100 nM) for $40 \mathrm{~h}$ and then treated with resveratrol for $24 \mathrm{~h}$. Cell lysates were analyzed for cell viability using CellTiter-Glo Luminescent assay. Plots are mean \pm S.E.M. $(n=3) .{ }^{*} P<0.05$ versus untreated control. ${ }^{\sharp} P<0.05$ for resveratrol-treated cells versus resveratrol-treated cells transfected with the miRNA mimic. (c) MCF-7 cells were transfected with miR-542-3p mimic (100 nM) for $40 \mathrm{~h}$ and then treated with resveratrol for $24 \mathrm{~h}$. Cell lysates were analyzed for Bcl-2 and XIAP expression levels by western blotting. Blots were reprobed with $\beta$-actin antibody to confirm equal loading of the samples. The immunoblot signals were quantified by densitometry. Values are mean \pm S.E.M. $(n=3) .{ }^{*} P<0.05$ versus untreated control. ${ }^{\#} P<0.05$ for resveratroltreated cells versus resveratrol-treated cells transfected with the miRNA mimic. (d) Cell cycle analysis of MCF-7 cells transfected with miR-542-3p mimic (100 nM) for $40 \mathrm{~h}$ and then treated with resveratrol for 24 h. Plots are mean \pm S.E.M. $(n=4)$

leukemic cells, ${ }^{32-35}$ Pozo-Guisado et al. ${ }^{36}$ reported no significant changes in cell cycle distribution of MDA-MB-231 cells treated with resveratrol treatment. Such differences may also be attributed to variations in experimental conditions used in these studies. Several studies have focused on utilizing small molecule inhibitors and molecules to specifically target IAPs and CDKs and this has been proven as a successful strategy for cancer treatment. ${ }^{37-39}$

We tested the effect of resveratrol on apoptosis-related miRNAs using human apoptosis miRNA array. MiRNAs are reported to have a pivotal role in breast cancer progression, functioning either as oncogenes or tumor-suppressor genes. MiRNAs have been shown to be dysregulated in breast cancer tissues as compared with normal tissues, ${ }^{40}$ and therefore could be important targets in cancer treatment. Several miRNAs with altered expression patterns are identified in various types of cancers. ${ }^{41,42}$ MiRNAs thus serve as therapeutic targets for cancer treatment because of their effect on multiple target genes and proteins. We report several miRNAs that were differentially regulated by resveratrol in MCF-7 and MDA-MB-231 cells (Table 1). Online databases such as TargetScan, miRBase and miRanda were used to identify major protein targets of the shortlisted miRNAs (Table 2). ${ }^{43-46}$ Two miRNAs in MCF-7 (miR-125b-5p and miR-542-3p) and two miRNAs in MDA-MB-231 (miR-200c-3p and miR-542-3p) were downregulated by over fivefolds. MiR-409-3p and miR-122-5p were the only upregulated miRNAs in MCF-7 and MDA-MB-231 cells, respectively. MiR-542-3p was downregulated in both the cell lines. Interestingly, all the shortlisted miRNAs were predicted to primarily target caspases, anti-apoptotic protein $\mathrm{Bcl}-2$ and cell cycle-related cyclins (Table 2). 


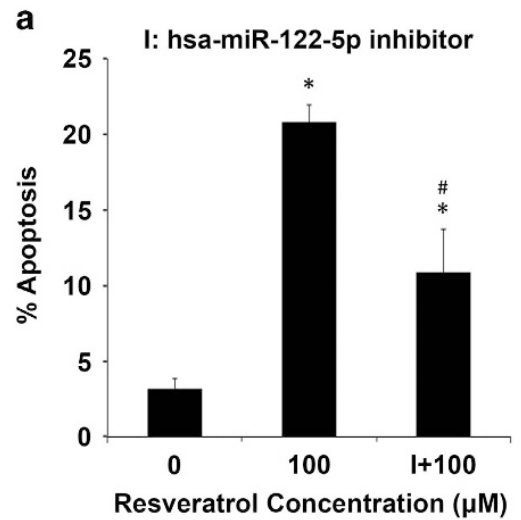

C
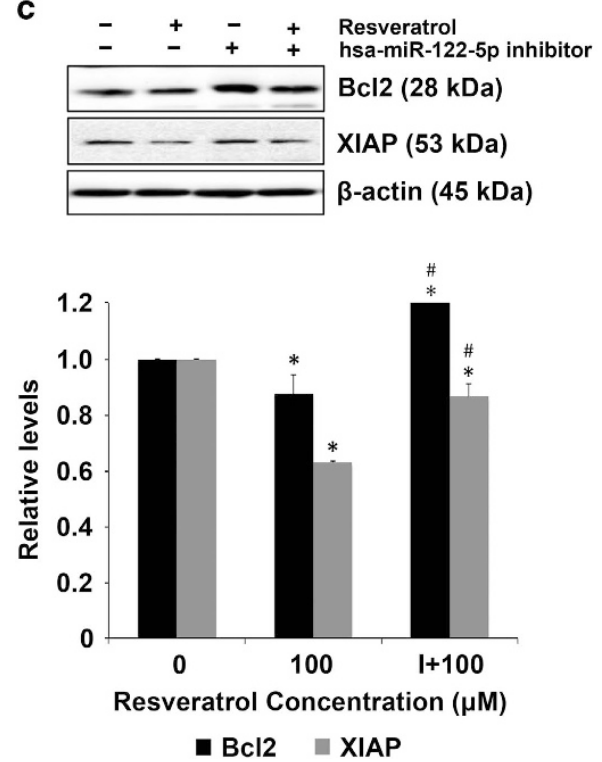

b

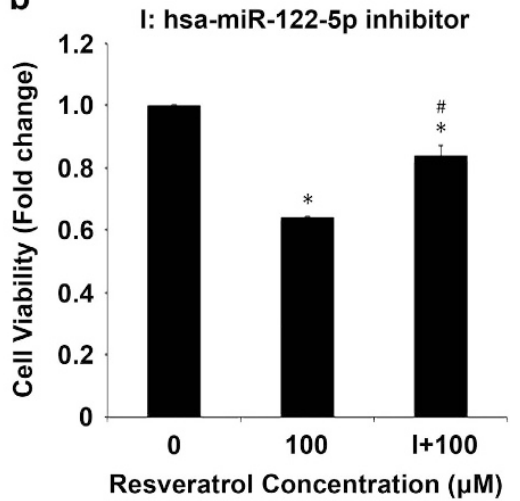

d 120

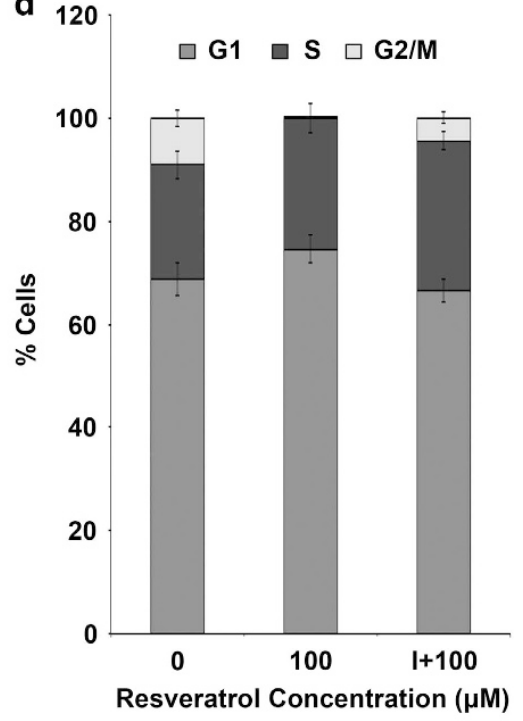

Figure 4 Effect of miR-122-5p modulation in MDA-MB-231 cells. (a) MDA-MB-231 cells were transfected with miR-122-5p inhibitor (100 nM) for $40 \mathrm{~h}$ and then treated with resveratrol for $24 \mathrm{~h}$. Apoptosis induction was assessed by Hoechst 33342 staining. (b) MDA-MB-231 cells were transfected with miR-122-5p inhibitor (100 $\mathrm{nM}$ ) for $40 \mathrm{~h}$ and then treated with resveratrol for $24 \mathrm{~h}$. Cell lysates were analyzed for cell viability using CellTiter-Glo Luminescent assay. Plots are mean \pm S.E.M. $(n=3)$. $P<0.05$ versus untreated control. ${ }^{\#} P<0.05$ for resveratrol-treated cells versus resveratrol-treated cells transfected with the miRNA inhibitor. (c) MDA-MB-231 cells were transfected with miR-122-5p inhibitor $(100 \mathrm{nM})$ for $40 \mathrm{~h}$ and then treated with resveratrol for $24 \mathrm{~h}$. Cell lysates were analyzed for Bcl-2 and XIAP expression levels by western blotting. Blots were reprobed with $\beta$-actin antibody to confirm equal loading of the samples. The immunoblot signals were quantified by densitometry. Values are mean \pm S.E.M. ( $n=3$ ). ${ }^{*} P<0.05$ versus nontreated control. ${ }^{\#} P<0.05$ for resveratrol-treated cells versus resveratrol-treated cells transfected with the miRNA inhibitor. (d) Cell cycle analysis of MDA-MB-231 cells transfected with miR-122-5p inhibitor $(100 \mathrm{nM})$ for $40 \mathrm{~h}$ and then treated with resveratrol for $24 \mathrm{~h}$. Plots are mean \pm S.E.M. $(n=4)$

To investigate the role of miRNA modulation in resveratrolinduced apoptosis of breast cancer cells, one miRNA that was the most affected by resveratrol treatment for each cell line was selected for further validation. Based on their maximum fold changes, miR-542-3p for MCF-7 and miR-122-5p for MDA-MB-231 cells were selected. Chemically synthesized miRNA mimic and inhibitors were used to validate miRNAs and study their effects on tumor inhibition. ${ }^{47,48}$ MCF-7 cells transfected with miR-542-3p mimic reversed the effect of resveratrol on apoptosis and the anti-apoptotic proteins $\mathrm{Bcl}-2$ and XIAP (Figure 3). Recent studies have shown that downregulation of miR-542-3p is associated with cancer invasiveness and resistance to therapy. ${ }^{49-51}$ Yoon et al. ${ }^{52}$ reported that the observed tumor-suppressive function of this miRNA is by targeting the anti-apoptotic protein survivin. In our study, we found that resveratrol downregulates miR-542-3p, which is imperative for the observed tumor inhibitory effects. Individual miRNA can be controlled by other miRNA as part of miRNA clusters, which varies in each system. This observation is particularly interesting because it highlights complex interactions among miRNAs that are yet to be understood. MDA-MB-231 cells transfected with miR-122-5p inhibitor showed similar resistance to resveratrol-induced apoptosis and reversed its effect on anti-apoptotic proteins (Figure 4). MiR-122-5p has been reported to regulate tumorigenesis in hepatocellular carcinoma ${ }^{53}$ and to have tumor-suppressive function in breast cancer. $^{54}$ Cell cycle analysis further revealed that the observed effects of resveratrol are through the identified miRNAs as there were lower percentage of MCF-7 and MDA-MB-231 cells transfected with miRNA 


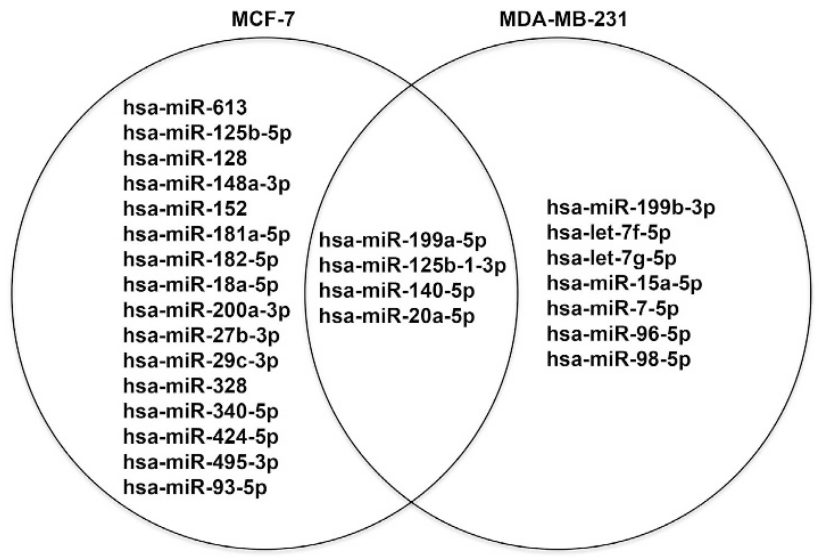

Figure 5 Venn diagram showing breast cancer miRNA microarray data for MCF-7 and MDA-MB-231 cells treated with $200 \mu \mathrm{m}$ resveratrol for $12 \mathrm{~h}$ as compared with untreated control cells that show at least a twofold change in miRNA that are differentially regulated

modulators in the $\mathrm{G} 1$ phase in response to resveratrol treatment. As compared with data in response to direct resveratrol treatment presented in Figure 2, the experimental and culture conditions are different in Figures 3 and 4, where cells were transfected with miRNA mimics or inhibitors before treating with resveratrol. Therefore, the effect observed on apoptosis, viability, cell cycle arrest, $\mathrm{Bcl}-2$ and XIAP proteins is less pronounced in cells, which were transfected before resveratrol treatment (Figures 3 and 4) as compared with direct treatment to resveratrol (Figure 2).

We also performed miRNA expression profiling using Breast Cancer arrays to identify key miRNAs known to be associated with breast cancer progression in response to resveratrol treatment (Figure 5 and Supplementary Table 3). Several miRNAs were modulated in MCF-7 and MDA-MB-231 cells in response to resveratrol treatment, of which four miRNAs associated with breast cancers including miR-199a$5 p$, miR-125b-1-3p, miR-140-5p and miR-20a-5p were common in both cell lines. These miRNAs have been widely reported to have a role in cancer initiation, progression and inhibition. MiR-199a-5p has been reported to suppress liver cancer by inhibiting glucose metabolism, regulate autophagic response in breast cancer and function as an oncogene in the development of gastric cancer. ${ }^{55-57}$ The miR-125b, miR-140 and miR-17/20 clusters are also reported to inhibit breast cancer progression. ${ }^{58-60}$ Validation of these miRNAs warrants further investigation and is beyond the scope of this study, which focuses on cell death and cell cycle pathways. Interestingly, miR-125b-1-3p is the only miRNA observed to be downregulated by resveratrol in both the apoptotic and breast cancer arrays. This provides extensive scope for further investigations as downregulation of miR-125b has been observed in head and neck cancer development and breast cancer progression. ${ }^{61,62}$

Overall, our findings demonstrate that resveratrol-induced apoptosis in MCF-7 and MDA-MB-231 cells and showed a dose-dependent effect on cell viability. Resveratrol mediated its apoptotic effect via caspase activation and downregulation of anti-apoptotic proteins including XIAP and $\mathrm{Bcl}-2$. Interestingly, resveratrol-modulated apoptotic miRNAs had a key role in mediating its effect on breast cancer cell death. Overall, our study reveals a novel role for resveratrol in inhibiting breast cancer progression by modulating tumorsuppressive miRNAs and thereby affecting cell cycle and apoptosis. We report novel miRNAs including miR-542-3p and $\mathrm{miR}-122-5 p$ to have a key role in resveratrol-mediated effects on MCF-7 and MDA-MB-231 breast cancer cells, respectively. Evaluating the potential of resveratrol to modulate epigenetic events associated with breast cancer could facilitate in the discovery and development of novel therapeutic strategies against this disease.

\section{Materials and Methods}

Chemicals and reagents. Resveratrol was obtained from Sigma-Aldrich (St. Louis, MO, USA). A $100 \mathrm{mM}$ stock was prepared in ethanol and stored at $4^{\circ} \mathrm{C}$ until further use. All antibodies including caspase-8, caspase-9, caspase-3, Bcl-2, XIAP, HRP-conjugated anti-rabbit IgG and anti-mouse IgG antibodies was purchased from Cell Signaling Technology (Danvers, MA, USA). $\beta$-Actin antibody, Hoechst 33342 and propidium iodide was purchased from Sigma-Aldrich.

Cell culture. Human breast adenocarcinoma cells MCF-7 and MDA-MB-231 were obtained from American Type Culture Collection (Manassas, VA, USA). Cells were cultured in Dulbecco's Modified Eagle medium (Thermo Scientific, Waltham, MA, USA) supplemented with 10\% FBS, $2 \mathrm{mM} \mathrm{L-glutamine,} 100 \mathrm{U} / \mathrm{ml}$ penicillin and $100 \mathrm{mg} / \mathrm{ml}$ streptomycin in a $5 \% \mathrm{CO}_{2}$ environment at $37^{\circ} \mathrm{C}$.

Apoptosis assay. Apoptosis was determined by Hoechst 33342 DNA fragmentation assay. Briefly, cells were incubated with $10 \mu \mathrm{g} / \mathrm{ml}$ Hoechst 33342 nuclear stain (Life Technologies, Carlsbad, CA, USA) for $30 \mathrm{~min}$ at $37^{\circ} \mathrm{C}$ and percentage of cells having intensely condensed chromatin and/or fragmented nuclei by fluorescence microscopy (EVOS All-in-one digital inverted fluorescence microscope, Thermo Fisher Scientific, Waltham, MA, USA) were scored. From random fields, nuclei were analyzed for each sample. The apoptotic index was calculated as apoptotic nuclei/total nuclei x $100(\%)$ using ImageJ software (Java image processing, $\mathrm{NIH}$, Bethesda, MD, USA).

Caspase assay. Caspase activity was determined by fluorometric assay using the enzyme substrate IETD-AMC for caspase-8 and LEHD-AMC for caspase-9, which are specifically cleaved by the respective enzymes at the Asp residue to release the fluorescent group, AMC. Cell extracts containing $50 \mu \mathrm{g}$ of protein were incubated with $100 \mathrm{mM}$ HEPES containing $10 \%$ sucrose, $10 \mathrm{mM}$ dithiothreitol, $0.1 \%$ 3-[(3-cholamidiopropyl)-dimethylammonio]-1-propane sulfonate and $50 \mathrm{mM}$ caspase substrate in a total reaction volume of $0.25 \mathrm{ml}$. The reaction mixture was incubated for $60 \mathrm{~min}$ at $37^{\circ} \mathrm{C}$, and quantified fluorometrically at the excitation and emission wavelengths of 380 and $460 \mathrm{~nm}$, respectively (Synergy H1 Hybrid Reader, BioTek, Winooski, VT, USA).

CellTiter-Glo luminescent cell viability assay. Breast cancer cells (MCF-7 and MDA-MB-231) treated with resveratrol were assessed for cell viability using CellTiter-Glo Luminescent cell viability assay (Promega, Madison, WI, USA) following the manufacturer's instructions. Briefly, $1 \times 10^{4}$ cells per well were seeded on a 96-well plate and the cells were incubated overnight. Luminescence was measured after cells were treated for $24 \mathrm{~h}$ and lysed with $50 \mu \mathrm{l}$ CellTiter-Glo reagent for 10-15 min (Synergy H1 Hybrid Reader, BioTek).

MTT assay. Breast cancer cells (MCF-7 and MDA-MB-231) were seeded in 96well plates and treated with indicated concentrations of resveratrol for $24 \mathrm{~h}$. Posttreatment, $20 \mu \mathrm{l}$ per well of MTT ( $5 \mathrm{mg} / \mathrm{ml}$ in PBS) was added and the plates were incubated at $37^{\circ} \mathrm{C}$. DMSO (200 $\mu$ l per well) was added and the dark blue formazan product was quantified by measuring absorbance at $570 \mathrm{~nm}$ (with a $690 \mathrm{~nm}$ reference filter; Synergy H1 Hybrid Reader, BioTek).

\section{MiRNA expression analysis and $q R T-P C R$}

(i) Isolation of RNA: total RNA was isolated using the miRNeasy mini kit (Qiagen) according to the manufacturer's instructions. The quality of RNA was assessed 

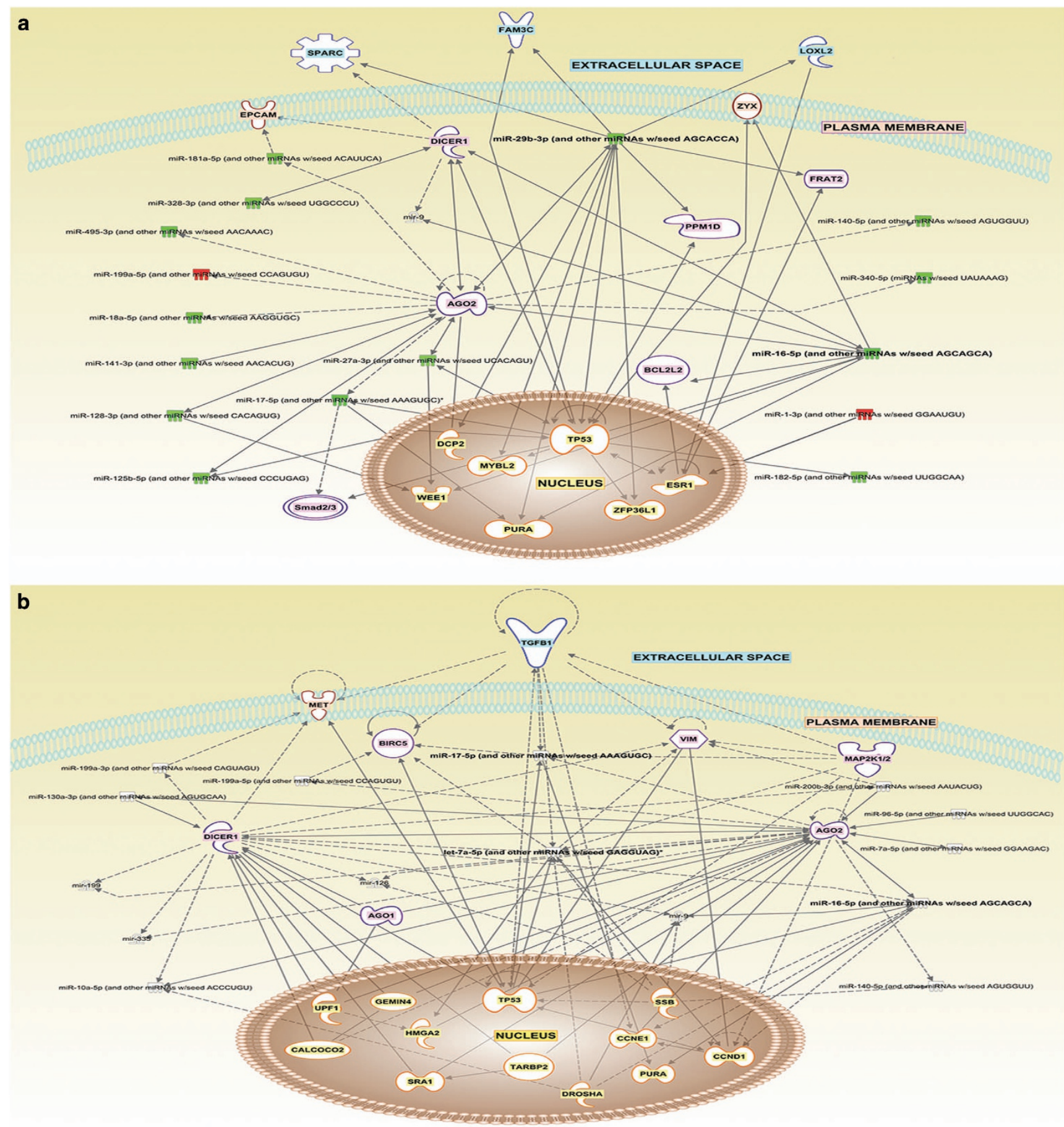

Figure 6 Path design analysis of breast cancer-related miRNAs. Network maps of important biomarkers predicted to have a key role in breast cancer in response to resveratrol treatment were generated using IPA. Potential protein and miRNA interactions were visualized using the Path Design Suite for both (a) MCF-7 and (b) MDA-MB-231 cells. Dotted lines connect genes that are known to be affected indirectly and solid lines connect genes that are known to be directly affected by resveratrol treatment

on a native agarose gel by analyzing the $18 \mathrm{~S}$ and $28 \mathrm{~S}$ ribosomal RNA bands and by measuring purity at 260 and 280 (data not shown).

(ii) miRNA amplification: CDNA synthesis was performed using the miScript II RT kit (Qiagen) as per the manufacturer's instructions. Real-time PCR amplification of the cDNA was performed using miScript SYBR Green PCR kit (Qiagen) for known apoptosis-related miRNA using Human Apoptosis
miRNA PCR arrays (Qiagen). cDNA conversion and real-time PCR were performed as per the manufacturer's instructions.

(iii) PCR array data analysis: data sets for each sample were collected at the same threshold and baseline levels to maintain consistency between samples for further analysis. The PCR array data were analyzed using the web-based data analysis software offered by Qiagen (http://pcrdataanalysis.sabiosciences. 
com/mirna/arrayanalysis.php). A twofold change cut-off was selected to identify miRNA that were significantly altered because of resveratrol treatment. The accession number and sequence of the identified miRNA were obtained using the miRBase (www.mirbase.org) database. miRWalk (http://www.umm. uni-heidelberg.de/apps/zmf/mirwalk/index.html) was used to obtain a list of predicted and validated miRNA targets from apoptosis-related pathways using the following pathway (database): Apoptosis (KEGG), Caspase (Biocarta), Death (Biocarta) and Mitochondria (Biocarta).

Transient transfection. MCF-7 and MDA-MB-231 cells were seeded in sixwell culture plates. The cells were transfected in complete medium with miRNA mimic, miRNA inhibitor or control (AllStars Hs Cell Death Control siRNA) (Qiagen) using Lipofectamine 3000 (Invitrogen, Carlsbad, CA, USA) transfecting agent according to the manufacturer's protocol. Briefly, lipofectamine $(15 \mu \mathrm{l})$ was added to miRNA mimic or miRNA inhibitor ( $100 \mathrm{nM}$ ) diluted with $50 \mu$ l serum-free medium. This complex was incubated for $15 \mathrm{~min}$ and then added to the cells. After $40 \mathrm{~h}$, the medium was discarded and the cells were washed with PBS and treated with resveratrol in serum-free medium.

Flow cytometry. MCF-7 and MDA-MB-231 cells were seeded in six-well culture plates and were treated in complete medium for cell cycle analysis. After $24 \mathrm{~h}$, cells were trypsinized and suspended in 70\% ethanol overnight. The cells were stained with $\mathrm{PI}$ and data acquisition was performed in a NovoCyte flow cytometer (ACEA Biosciences, Inc., San Diego, CA, USA) using NovoExpress 1.0.2 software. For transfection experiments, cells were transfected in complete medium for $40 \mathrm{~h}$ and then treated in serum-free medium for $24 \mathrm{~h}$.

Gating strategy. Acquired samples were initially screened with SSC-H versus FSC-H density plot in linear scale and the gates were set to exclude debris. Another density plot was generated with the cells in the set gates and analyzed in PE-H versus PE-A for doublet discrimination. Singlet cells were gated, exported as FCS files and analyzed using ModFit 4.0.5 LT cell cycle analysis software (Verity Software House, Topsham, ME, USA).

Western blotting. After specific treatments, cell lysates were resolved on a $10 \%$ sodium dodecyl sulfate-polyacrylamide gel electrophoresis and transferred onto a nitrocellulose membrane. The protein concentration was determined using a bicinchoninic acid protein assay kit (Pierce Biotechnology, Rockford, IL, USA), and equal amount of protein was loaded per sample. The membrane was blocked with TBS-T (0.1\% Tween-20 in TBS) containing 5\% dry milk, and incubated with primary antibody overnight at $4^{\circ} \mathrm{C}$. After three washes with TBS-T, the membrane was incubated with HRP-conjugated secondary antibody for $1 \mathrm{~h}$ and then washed with TBS-T. The immune complexes were detected by chemiluminescence (Supersignal West Femto; Pierce Biotechnology) using MyECL Imager (Thermo Scientific), and quantified by using ImageJ ( $\mathrm{NIH}$, Image analysis using Java) digitizing software. Mean densitometry data from independent experiments were normalized to the control.

Path design analysis. The IPA platform was used to discern global interaction networks associated with miRNA that were differentially regulated in MCF-7 and MDA-MB-231 cells. The miRNA data were uploaded into the software, and Network analysis was performed to identify important regulatory proteins associated with regulation of the miRNA. These protein pathways and miRNA were mapped out using the Path Design tool available to aid in visualization of interactions across various cellular compartments.

Statistical analysis. Representative data from three or more independent experiments are shown as mean value \pm S.E.M. Statistical analysis was performed with two-way analysis of variance to identify differences between groups using GraphPad Prism Software (San Diego, CA, USA) and $P$ values $<0.05$ considered significant.

\section{Conflict of Interest}

The authors declare no conflict of interest.

Acknowledgements. This work was supported by grants from National Institutes of Health (HL112630 and CA173069).
1. American Cancer Society. Cancer Facts and Figures 2015. American Cancer Society: Atlanta, GA, 2015

2. Shapiro Gl, Harper JW. Anticancer drug targets: cell cycle and checkpoint control. J Clin Invest 1999; 104: 1645-1653.

3. Dickson MA, Schwartz GK. Development of cell-cycle inhibitors for cancer therapy. Curr Oncol 2009; 16: 36-43.

4. Senderowicz AM. The cell cycle as a target for cancer therapy: basic and clinical findings with the small molecule inhibitors flavopiridol and UCN-01. Oncologist 2002; 7: 12-19.

5. Kong Y, Chen J, Zhou Z, Xia H, Qiu MH, Chen C. Cucurbitacin E induces cell cycle G2/M phase arrest and apoptosis in triple negative breast cancer. PLoS One 2014; 9: e103760.

6. Wang Z, Li W, Meng X, Jia B. Resveratrol induces gastric cancer cell apoptosis via reactive oxygen species, but independent of sirtuin1. Clin Exp Pharmacol Physiol 2012; 39: 227-232.

7. Tan TW, Tsai HR, Lu HF, HL Lin, Tsou MF, Lin YT et al. Curcumin-induced cell cycle arrest and apoptosis in human acute promyelocytic leukemia HL-60 cells via MMP changes and caspase-3 activation. Anticancer Res 2006; 26: 4361-4371.

8. van Ginkel PR, Sareen D, Subramanian L, Walker Q, Darjatmoko SR, Lindstrom MJ et al. Resveratrol inhibits tumor growth of human neuroblastoma and mediates apoptosis by directly targeting mitochondria. Clin Cancer Res 2007; 13: 5162-5169.

9. Hwang JT, Kwak DW, Lin SK, Kim HM, Kim YM, Park OJ. Resveratrol induces apoptosis in chemoresistant cancer cells via modulation of AMPK signaling pathway. Ann N Y Acad Sci 2007: 1095: 441-448.

10. Tang HY, Shih A, Cao HJ, Davis FB, Davis PJ, Lin HY. Resveratrol-induced cyclooxygenase2 facilitates p53-dependent apoptosis in human breast cancer cells. Mol Cancer Ther 2006; 5: 2034-2042.

11. Soo E, Thakur S, Qu Z, Jambhrunkar S, Parekh HS, Popat A. Enhancing delivery and cytotoxicity of resveratrol through a dual nanoencapsulation approach. J Colloid Interface Sci 2016; 462: 368-374.

12. Alkhalaf M, El-Mowafy A, Renno W, Rachid O, Ali A, Al-Attyiah R. Resveratrol-induced apoptosis in human breast cancer cells is mediated primarily through the caspase-3dependent pathway. Arch Med Res 2008; 39: 162-168.

13. Pozo-Guisado E, Merino JM, Mulero-Navarro S, Lorenzo-Benayas MJ, Centeno F, Alvarez-Barrientos A et al. Resveratrol-induced apoptosis in MCF-7 human breast cancer cells involves a caspase-independent mechanism with downregulation of $\mathrm{Bcl}-2$ and $\mathrm{NF}$ kappaB. Int J Cancer 2005; 115: 74-84.

14. Mohapatra P, Preet R, Choudhuri M, Choudhuri T, Kundu CN. 5-Fluorouracil increases the chemopreventive potentials of resveratrol through DNA damage and MAPK signaling pathway in human colorectal cancer cells. Oncol Res 2011; 19: 311-321.

15. Sareen D, Darjatmoko SR, Albert DM, Polans AS. Mitochondria, calcium, and calpain are key mediators of resveratrol-induced apoptosis in breast cancer. Mol Pharmacol 2007; 72: 1466-1475.

16. Wolfson B, Eades G, Zhou Q. Roles of microRNA-140 in stem cell-associated early stage breast cancer. World J Stem Cells 2014; 6: 591-597.

17. Isobe T, Hisamori S, Hogan DJ, Zabala M, Hendrickson DG, Dalerba P et al. miR-142 regulates the tumorigenicity of human breast cancer stem cells through the canonical WNT signaling pathway. Elife 2014; 3: e01977.

18. Lim WK, Micklem G. MicroRNAs dysregulated in breast cancer preferentially target key oncogenic pathways. Mol Biosyst 2011; 7: 2571-2576.

19. Dhar S, Hicks C, Levenson AS. Resveratrol and prostate cancer: promising role for microRNAs. Mol Nutr Food Res 2011; 55: 1219-1229.

20. Jiang $\mathrm{L}$, Tao $\mathrm{C}, \mathrm{He} A, \mathrm{He} X$. Overexpression of miR-126 sensitizes osteosarcoma cells to apoptosis induced by epigallocatechin-3-gallate. World J Surg Oncol 2014; 12: 383.

21. Sethi S, Li Y, Sarkar FH. Regulating miRNA by natural agents as a new strategy for cancer treatment. Curr Drug Targets 2013; 14: 1167-1174.

22. Li Y, Kong D, Ahmad A, Bao B, Dyson G, Sarkar FH. Epigenetic deregulation of miR-29a and miR-1256 by isoflavone contributes to the inhibition of prostate cancer cell growth and invasion. Epigenetics 2012; 7: 940-949.

23. Hui C, Yujie F, Lijia Y, Long Y, Hongxia X, Yong $Z$ et al. MicroRNA-34a and microRNA-21 play roles in the chemopreventive effects of 3,6-dihydroxyflavone on 1-methyl-1-nitrosoureainduced breast carcinogenesis. Breast Cancer Res 2012; 14: R80.

24. Alayev A, Berger SM, Kramer MY, Schwartz NS, Holz MK. The combination of rapamycin and resveratrol blocks autophagy and induces apoptosis in breast cancer cells. J Cell Biochem 2015; 116: 450-457.

25. Khan MA, Chen HC, Wan XX, Tania M, Xu AH, Chen FZ et al. Regulatory effects of resveratrol on antioxidant enzymes: a mechanism of growth inhibition and apoptosis induction in cancer cells. Mol Cells 2013; 35: 219-225.

26. Shi Y, Yang S, Troup S, Lu X, Callaghan S, Park DS et al. Resveratrol induces apoptosis in breast cancer cells by E2F1-mediated up-regulation of ASPP1. Oncol Rep 2011; 25: 1713-1719.

27. Ferraz da Costa DC, Casanova FA, Quarti J, Malheiros MS, Sanches D, Dos Santos PS et al. Transient transfection of a wild-type p53 gene triggers resveratrol-induced apoptosis in cancer cells. PLoS One 2012; 7: e48746.

28. Olsson M, Zhivotovsky B. Caspases and cancer. Cell Death Differ 2011; 18: 1441-1449.

29. Clément MV, Hirpara JL, Chawdhury SH, Pervaiz S. Chemopreventive agent resveratrol, a natural product derived from grapes, triggers CD95 signaling-dependent apoptosis in human tumor cells. Blood 1998; 92: 996-1002. 
30. Delmas D, Rébé C, Lacour S, Filomenko R, Athias A, Gambert P et al. Resveratrol-induced apoptosis is associated with Fas redistribution in the rafts and the formation of a deathinducing signaling complex in colon cancer cells. J Biol Chem 2003; 278: 41482-41490.

31. Ganapathy S, Chen Q, Singh KP, Shankar S, Srivastava RK. Resveratrol enhances antitumor activity of TRAIL in prostate cancer xenografts through activation of FOXO transcription factor. PLoS One 2010; 5: e15627.

32. Quoc Trung L, Espinoza JL, Takami A, Nakao S. Resveratrol induces cell cycle arrest and apoptosis in malignant NK cells via JAK2/STAT3 pathway inhibition. PLoS One 2013; 8: e55183.

33. Hahnvajanawonga C, Ketnimita S, Boonyanugomola W, Pattanapanyasatd K, Chamgramole $Y$, Sripae $B$ et al. Inhibition of cell cycle progression and apoptotic activity of resveratrol in human intrahepatic cholangiocarcinoma cell lines. Asian Biomed 2011; 5: 775-785.

34. Benitez DA, Pozo-Guisado E, Alvarez-Barrientos A, Fernandez-Salguero PM, Castellón EA Mechanisms involved in resveratrol-induced apoptosis and cell cycle arrest in prostate cancer-derived cell lines. J Androl 2007; 28: 282-293.

35. Kotha A, Sekharam M, Cilenti L, Siddiquee K, Khaled A, Zervos AS et al. Resveratrol inhibits Src and Stat3 signaling and induces the apoptosis of malignant cells containing activated Stat3 protein. Mol Cancer Ther 2006; 5: 621-629.

36. Pozo-Guisado E, Alvarez-Barrientos A, Mulero-Navarro S, Santiago-Josefat B, Fernandez-Salguero PM. The antiproliferative activity of resveratrol results in apoptosis in MCF-7 but not in MDA-MB-231 human breast cancer cells: cell-specific alteration of the cell cycle. Biochem Pharmacol 2002; 64: 1375-1386.

37. Shapiro Gl. Cyclin-dependent kinase pathways as targets for cancer treatment. J Clin Oncol 2006; 24: 1770-1783

38. Dong F, Guo W, Zhang L, Wu S, Teraishi F, Davis JJ et al. Downregulation of XIAP and induction of apoptosis by the synthetic cyclin-dependent kinase inhibitor GW8510 in nonsmall cell lung cancer cells. Cancer Biol Ther 2006; 5: 165-170.

39. Mani S, Wang C, Wu K, Francis R, Pestell R. Cyclin-dependent kinase inhibitors: novel anticancer agents. Expert Opin Investig Drugs 2000; 9: 1849-1870.

40. Adams BD, Guttilla IK, White BA. Involvement of microRNAs in breast cancer. Semin Reprod Med 2008; 26: 522-536

41. Sun X, Luo S, He Y, Shao Y, Liu C, Chen $Q$ et al. Screening of the miRNAs related to breast cancer and identification of its target genes. Eur J Gynaecol Oncol 2014; 35: 696-700.

42. Tong AW, Nemunaitis J. Modulation of miRNA activity in human cancer: a new paradigm for cancer gene therapy? Cancer Gene Ther 2008; 15: 341-355.

43. Kozomara A, Griffiths-Jones S. miRBase: integrating microRNA annotation and deepsequencing data. Nucleic Acids Res 2011; 39: D152-D157.

44. Griffiths-Jones S, Saini HK, van Dongen S, Enright AJ. miRBase: tools for microRNA genomics. Nucleic Acids Res 2008; 36: D154-D158.

45. Griffiths-Jones S, Grocock RJ, van Dongen S, Bateman A, Enright AJ. miRBase: microRNA sequences, targets and gene nomenclature. Nucleic Acids Res 2006; 34: D140-D144.

46. Griffiths-Jones S. The microRNA registry. Nucleic Acids Res 2004; 32: D109-D111.

47. Jurmeister S, Baumann M, Balwierz A, Keklikoglou I, Ward A, Uhlmann S et al. MicroRNA-200c represses migration and invasion of breast cancer cells by targeting actinregulatory proteins FHOD1 and PPM1F. Mol Cell Biol 2012; 32: 633-651.

48. Basu A, Jiang X, Negrini M, Haldar S. MicroRNA-mediated regulation of pancreatic cance cell proliferation. Oncol Lett 2010; 1: 565-568.

49. Chen BB, Chen XB, Bie LY, Mu Y, Wang HL, Lv HF et al. Decreased expression of miR-542$3 p$ exerts growth inhibitory functions in esophageal cancer. J Can Res Ther 2015; 11: 24-28.
50. Cai J, Zhao J, Zhang N, Xu X, Li R, Yi Y et al. MicroRNA-542-3p suppresses tumor cell invasion via targeting AKT pathway in human astrocytoma. J Biol Chem 2015; 290 : 24678-24688.

51. Kumar S, Kumar A, Shah PP, Rai SN, Panguluri SK, Kakar SS. MicroRNA signature of cis-platin resistant vs. cis-platin sensitive ovarian cancer cell lines. J Ovarian Res 2011; 4: 17.

52. Yoon S, Choi YC, Lee S, Jeong Y, Yoon J, Baek K. Induction of growth arrest by miR-542-3p that targets surviving. FEBS Lett 2010; 584: 4048-4052.

53. Nassirpour R, Mehta PP, Yin MJ. miR-122 regulates tumorigenesis in hepatocellular carcinoma by targeting AKT3. PLOS One 2013; 8: e79655.

54. Ergun S, Ulasli M, Igci $\mathrm{YZ}$, Igci M, Kirkbes $\mathrm{S}$, Borazan $\mathrm{E}$ et al. The association of the expression of miR-122-5p and its target ADAM10 with human breast cancer. Mol Biol Rep 2015; 42: 497-505.

55. Guo W, Qiu Z, Wang Z, Wang Q, Tan N, Chen T et al. MiR-199a-5p is negatively associated with the malignancies and regulates glycolysis and lactate production by targeting hexokinase 2 in liver cancer. Hepatology 2015; 62: 1132-1144.

56. He XJ, Ma YY, Yu S, Jiang XT, Lu YD, Tao L et al. Up-regulated miR-199a-5p in gastric cancer functions as an oncogene and targets klotho. BMC Cancer 2014; 14: 218.

57. Yi H, Liang B, Jia J, Liang N, Xu H, Ju G et al. Differential roles of miR-199a-5p in radiationinduced autophagy in breast cancer cells. FEBS Lett 2013; 587: 436-443.

58. Li Q, Yao Y, Eades G, Liu Z, Zhang Y, Zhou Q. Downregulation of miR-140 promotes cancer stem cell formation in basal-like early stage breast cancer. Oncogene 2014; 33 : 2589-2600.

59. Akhavantabasi S, Sapmaz A, Tuna S, Erson-Bensan AE. miR-125b targets ARID3B in breast cancer cells. Cell Struct Funct 2012; 37: 27-38.

60. Yu Z, Willmarth NE, Zhou J, Katiyar S, Wang M, Liu Y et al. microRNA 17/20 inhibits cellular invasion and tumor metastasis in breast cancer by heterotypic signaling. Proc Natl Acad Sci USA 2010; 107: 8231-8236.

61. Nakanishi H, Taccioli C, Palatini J, Fernandez-Cymering C, Cui R, Kim T et al. Loss of miR-125b-1 contributes to head and neck cancer development by dysregulating TACSTD2 and MAPK pathway. Oncogene 2014; 33: 702-712.

62. Feliciano A, Castellvi J, Artero-Castro A, Leal JA, Romagosa C, Hernandez-Losa J et al. miR-125b acts as a tumor suppressor in breast tumorigenesis via its novel direct targets ENPEP, CK2- $\alpha$, CCNJ, and MEGF9. PLOS One 2013; 8: e76247.

(c) Cell Death and Disease is an open-access journal published by Nature Publishing Group. This work is licensed under a Creative Commons Attribution 4.0 International License. The images or other third party material in this article are included in the article's Creative Commons license, unless indicated otherwise in the credit line; if the material is not included under the Creative Commons license, users will need to obtain permission from the license holder to reproduce the material. To view a copy of this license, visit http://creativecommons.org/licenses/by/4.0/ 